\title{
PENGEMBANGAN PERMAINAN PASSING BAWAH MELALUI PERMAINAN 2 ON 2 DALAM EKSTRAKULIKULER
}

\author{
Dhoni kurniawan $^{1}$, Pandu Kresnapati ${ }^{2}$, Muh Isna Nur Wibisana ${ }^{3}$ \\ ${ }^{1}$ FPIPSKR, Universitas PGRI Semarang \\ Email: dhonikurniawan25@gmail.com \\ ${ }^{2}$ FPIPSKR, Universitas PGRI Semarang \\ Email: pandukresnapati@upgris.ac.id \\ ${ }^{3}$ FPIPSKR, Universitas PGRI Semarang \\ Email: muhisnanurdinwibisana@upgris.ac.id
}

\begin{tabular}{l}
\hline Artikel Info \\
\hline Koresponden penulis: Dhoni Kurniawan \\
Email. dhonikurniawan25@gmail.com \\
$\square$ Diterima 9 April 2021 \\
$\square$ Direview 11 April 2021 \\
$\square$ Disetujui 16 April 2021 \\
$\square$ Dipublikasi 17 April 2021 \\
Kata Kunci: \\
Pengembangan, permainan, passiang \\
bawah, bola volly
\end{tabular}

Pengembangan, permainan, passiang
bawah, bola volly

$\underline{\text { Keywords: }}$

Development, play, underpass, volleyball

\begin{abstract}
Abstrak
Tujuan Penelitian ini adalah untuk menghasilkan bentuk permainan passing bawah bola voli dalam kegiatan ekstrakurikuler bola voli di SMK N 2 Blora. Dalam penelitian ini mengacu pada pengembangan Research \& Develepment $(R \& D) . \quad$ Dari data hasil penelitian, deskripsi presentase data evaluasi ahli yaitu, ahli Penjas 95\% (sangat baik), ahli pembelajaran bola voli 95\% (sangat baik), dari uji coba lapangan skala kecil didapat hasil kuesioner siswi ratarata persentase pilihan jawaban yang sesuai 67,4\% (baik).Sedangkan untuk uji coba lapangan skala besar didapat hasil evaluasi ahli yaitu, ahli Penjas $83 \%$ (baik), ahli pembelajaran bola voli 95\% (sangat baik). Dari uji coba lapangan skala besar didapat hasil kuesioner siswa rata-rata presentase pilihan jawaban yang sesuai $83 \%$ (baik).
\end{abstract}

\begin{abstract}
The purpose of this study was to produce a form of volleyball passing under the game in volleyball extracurricular activities at SMK N 2 Blora. In this research, it refers to the development of Research \& Development $(R \& D)$. From the research data, the description of the percentage of expert evaluation data, namely, Physical Education experts 95\% (very good), Volleyball learning experts $95 \%$ (very good), from small-scale field trials the results obtained from student questionnaires the average percentage of appropriate answer choices $67.4 \%$ (good). Meanwhile, for large-scale field trials the results of expert evaluations were obtained, namely, Physical Education experts $83 \%$ (good), volleyball learning experts $95 \%$ (very good). From large-scale field trials, it was found that the results of the student questionnaire averaged the percentage of appropriate answer choices $83 \%$ (good).
\end{abstract}




\section{PENDAhULUAN}

Pendidikan Jasmani dan Kesehatan pada hakekatnya adalah proses pendidikan yang memanfaatkan aktifitas fisik dan kesehatan utuk menghasilkan perubahan holistic dan kualitas individu, baik dalam hal fisik, mental, serta emosional. Pendidikan jasmani memperlakukan anak sebagai sebuah kesatuan utuh, dari pada hanya menganggapnya sebagai seseorang yang terpisah kualitas fisik dan mentalnya. Bila ditinjau dari per definisi, pendidikan jasmani diartikan berbagai ungkapan dan kalimat. Namun esensinya sama, yang disampaikan bermakna dan jelas, bahwa pendidikan jasmani memanfaatkan alat fisik untuk mengembangkan keutuhan manusia. Pendidikan jasmani ini karenanya harus menyebabkan perbaikan dalam pikiran dan tubuh yang mempengaruhi seluruh aspek dan jiwa kehidupan seseorang. Pendekatan holistik tubuh-jiwa ini termasuk pula penekanan pada ketiga domain pendidikana; psikomotor, kognitif dan afektif. Menurut Fuad Ihsan (2008: 1).

pendidikan sebagai usaha manusia untuk menumbuhkan dan mengembangkan potensi-potensi pembawaan baik jasmani maupun rohani sesuai dengan nilai-nilai yang ada dalam masyarakat dan kebudayaan. Usaha-usaha yang dilakukan untuk menanamkan nilai-nilai dan norma-norma tersebut serta mewariskannya kepada generasi berikutnya untuk dikembangkan dalam hidup dan kehidupan yang terjadi dalam suatu proses pendidikan. Sutomo, dkk (2007: 37).

Bola voli merupakan cabang olahraga yang sudah tidak asing lagi bagi masyarakat di Indonesia, baik masyarakat perkotaan maupun masyarakat pedesaan karena untuk melakukan olahraga ini tidak membutuhkan biaya yang terlalu banyak, sarana dan prasaranya pun mudah didapatakan. Banyak masyarakat yang menyukai olahraga ini sehingga banyak pula masyarakat yang ingin mempelajari permainan bola voli ini secara lebih jauh. Sekolah merupakan salah satu tempat yang tepat untuk bisa belajar tentang permainan bola voli dengan teknik- teknik yang benar. Dalam permainan bola voli ada beberapa bentuk teknik dasar yang harus dikuasai. Teknkteknik dalam permainan bola voli terdiri atas servis, passing, block, dan smash".Dari keempat teknik dasar diatas passing merupakan salah satu teknik yang penting dan fundamental dalam permainan bola voli. Bagi para pemula selain servis, passing bawah sangat menentukan jalannya permainan pada bola voli, oleh karena itu untuk pembelajaran bola voli di sekolah passing bawah adalah teknik terpenting yang harus dipelajari dan di kuasai dengan baik oleh peserta didik. Menurut Nuril Ahmadi (2007:20).

Berdasarkan hasil observasi yang telah dilakukan di Smk N 2 Blora dengan melakukan wawancara dan diskusi dengan salah satu guru Penjas, diperoleh informasi bahwa di Smk N 2 Blora minat siswi dalam 
mengikuti penjas masih kurang, dimana siswi lebih suka duduk-duduk atau bergurau sendiri, pada saat jam pelajaran Pendidikan Jasmani Kesehatan dan Rekreasi/pada saat ekstrakurikuler bola voli khususnya passing bawah bola voli. Hanya beberapa siswi yang benar benar mengikuti pelajaran penjas dengan baik dan sungguh-sungguh.

Banyak faktor yang menjadi penyebab kurangnya minat siswi dalam mengikuti pelajaran penjas yang pada akhirnya akan berpengaruh terhadap nilai penjas itu sendiri. Salah satunya adalah faktor internal pada siswi, dimana siswi merasa jenuh atau bosan dengan materi yang diajarkan oleh guru, karena guru hanya memberikan materi pokok tanpa disertai permainan atau variasi pembelajaran yang menarik yang dapat meningkatkan minat atau motivasi siswi dalam mengikuti pembelajaran penjas. Sehingga perlu diadakannya materi pembelajaran yang bervariasi dan menarik yang sesuai dengan karakteristik siswi Smk khususnya yang mengikuti Ekstrakurikuler bola voli. Sehingga apa salahnya guru menerapkan permainan yang berupa permainan passing bawah bola voli 2 on 2 , siswi tidak hanya bermain saja tapi juga belajar.

Oleh karena itu perlunya metode yang mampu memotivasi siswi untuk bergerak, salah satunya adalah metode permainan passing bawah bola voli menggunakan permainan 2 on 2. Dimana dengan permainan ini selain bertujuan untuk meningkatkan keterampilan siswi dalam mengikuti ekstrakurikuler bola voli disekolah, yang pada akhirnya dengan adanya minat siswi tersebut diharapkan dapat meningkatkan kemampuan siswi dalam melakukan passing bawah bola voli. Sehingga dengan diterapkannya modifikasi permainan tersebut dalam kegiatan ekstrakurikuler dapat menciptakan proses permainan yang menyenangkan dan tercapainya tujuan dari permainan tersebut. Permainan 2 on 2 merupakan suatu modifikasi permainan bola voli yang diciptakan untuk menarik minat siswi dalam mengikuti kegiatan ekstrakurikuler bola voli dan juga dapat membantu meningkatkan kemampuan siswi dalam melakukan passing bawah bola voli.

\section{KAJIAN LITERATUR DAN PEGEMBANGAN HIPOTESIS}

A. Pengertian Bola Voli

Sejarah Bola Voli Pada awal penemuannya, olahraga permainan bola voli ini diberi nama Mintonette. Olahraga Mintonette ini pertama kali ditemukan oleh seorang Instruktur pendidikan jasmani (Director of Phsycal Education) yang bernama William G. Morgan di YMCA pada tanggal 9 Februari 1895, di Holyoke, Massachusetts (Amerika Serikat). YMCA (Young Men's Christian Association) merupakan sebuah organisasi yang didedikasikan untuk mengajarkan ajaranajaran pokok umat Kristen kepada para pemuda, seperti yang telah diajarkan oleh Yesus. Organisasi ini didirikan pada tanggal $\underline{6}$ 
$\underline{\text { Juni }} 1884$ di London, Inggris oleh George William. Setelah bertemu dengan James Naismith (seorang pencipta olahraga bola basket yang lahir pada tanggal 6 November 1861, dan meninggal pada tanggal 28 November 1939), Morgan menciptakan sebuah olahraga baru yang bernama Mintonette. Sama halnya dengan James Naismith, William G. Morgan juga mendedikasikan hidupnya sebagai seorang instruktur pendidikan jasmani. William G. Morgan yang juga merupakan lulusan Springfield College of YMCA, menciptakan permainan Mintonette ini empat tahun setelah diciptakannya olahraga permainan basketball oleh James Naismith. Olahraga permainan Mintonette sebenarnya merupakan sebuah permainan yang diciptakan dengan mengkombinasikan beberapa jenis permainan. Tepatnya, permainan Mintonette diciptakan dengan mengadopsi empat macam karakter olahraga permainan menjadi satu, yaitu bola basket, baseball, tenis, dan yang terakhir adalah bola tangan (handball). Pada awalnya, permainan ini diciptakan khusus bagi anggota YMCA yang sudah tidak berusia muda lagi, sehingga permainan ini-pun dibuat tidak seaktif permainan bola basket.

Perubahan nama Mintonette menjadi volley ball (bola voli) terjadi pada tahun 1896, pada demonstrasi pertandingan pertamanya di International YMCA Training School. Pada awal tahun 1896 tersebut, Dr. Luther Halsey Gulick (Director of the Professional Physical
Education Training School sekaligus sebagai Executive Director of Department of Physical Education of the International Committe of YMCA) mengundang dan meminta Morgan untuk mendemonstrasikan permainan baru yang telah ia ciptakan di stadion kampus yang baru. Pada sebuah konferensi yang bertempat di kampus YMCA, Springfield tersebut juga di hadiri oleh seluruh instruktur pendidikan jasmani. Dalam kesempatan tersebut, Morgan membawa dua tim yang pada masing-masing tim beranggotakan lima orang. Dalam kesempatan itu, Morgan juga menjelaskan bahwa permainan tersebut adalah permainan yang dapat dimainkan di dalam maupun di luar ruangan dengan sangat leluasa. Dan menurut penjelasannya pada saat itu, permainan ini dapat juga dimainkan oleh banyak pemain. Tidak ada batasan jumlah pemain yang menjadi standar dalam permainan tersebut. Sedangkan sasaran dari permainan ini adalah mempertahankan bola agar tetap bergerak melewati net yang tinggi,dari satu wilayah ke wilayah lain(wilayah lawan).(agus kristiyanto:9)

Bola voli masuk ke Indonesia pada tahun 1928 yang dibawa oleh serdadu-serdadu Belanda dan guru (pelatih) yang didatangkan dari Belanda sewaktu mereka bertugas di Indonesia. Setelah Indonesia merdeka, bekas Angkatan Perang Belanda yang bergabung dengan TNI, ikut mempopulerkan bola voli.Pada PON III tahun 1953 di Medan (Sumatera Utara), bola voli mulai 


\section{Journal STAND: Sports and Development}

http://jurnal.unipasby.ac.id/index.php/stand/about/submissions jurnal.stand@unipasby.ac.id

dipertandingkan. Pada tahun 1954, Surabaya dan Jakarta mulai membentuk organisasi bola voli nasional, atas jasa Azis Saleh yang waktu itu menjabat komisaris teknik KOI.Setelah diadakan pertemuan IBVOS (Surabaya) dan PERVID (Jakarta), bersepakat membentuk organisasi bola voli nasional. Dan pada tanggal 20 Januari 1955 lahirlah Organisasi Persatuan Bola Voli Seluruh Indonesia, yang disingkat dengan PBVSI dengan ketua W. J. Latumeten (Munasifah, 2008:3).

\section{B. Pengertian Pendidikan Jasmani}

Menurut Ega Trisni Rahaya (2013:7) pendidikan jasmani adalah proses pendidikan yang memanfaatkan aktivitas jasmani yang direncanakan secara sistematik bertujuan untuk mengembangkan dan meningkatkan individu secara organik, neuromuskuler, perseptual, kognitif, dan emosional, dalam kerangka sistem pendidikan nasional.

Menurut Samsudin (2008:2) Pendidikan jasmani adalah suatu proses pembelajaran melalui aktivitas jasmani yang didesain untuk meningkatkan kebugaran jasmani, mengembangkan keterampilan motorik, pengetahuan dari perilaku hidup sehat dan aktif, sikap sportif, dan kecerdasan emosi. Lingkungan belajar diatur secara saksama untuk meningkatkan pertumbuhan dan perkembangan seluruh ranah, jasmani, psikomotor, kognitif, dan afektif setiap siswi.

C. Tekhnik Dasar Bola Voli

Dalam permainan bola voli ada beberapa teknik dasar bola voli yaitu;
Service,Block,Smash, dan Passing, Menurut (Herry Koesyanto, 2003:10)

Keterampilan adalah kemampuan gerak dengan tingkat tertentu, Istilah keterampilan juga diartikan sebagai perbuatan atau suatu tingkat kemahiran. Sebagai kompetensi yang diperagakan oleh seseorang dalam melaksanakan tugas yang berkaitan dengan pencapaian suatu tujuan. Untuk memperoleh tingkat keterampilan diperlukan pengetahuan yang mendasar tentang bagaimana keterampilan tertentu bisa dihasilkan atau diperoleh serta faktor-faktor apa saja yang berperan dalam mendorong penguasaan keterampilan. Pada intinya bahwa suatu keterampilan itu baru dapat dikuasai atau diperoleh apabila dipelajari atau dilatih dengan persyaratan tertentu, satu diantaranya adalah kegiatan pembelajaran atau latihan keterampilan teersebut dilakukan secara terus menerus dalam jangka waktu yang memadai. Pada hakikatnya seluruh tugas dalam kehidupan sehari-hari senantiasa melibatkan berbagai keterampilan. Keterampilan itu baru dapat diperoleh apabila dilaksanakan melalui proses pembelajaran atau pelatihan (Amung Ma'mun dan Yudha, 2000: 57-59).

D. Model Permainan Passing bawah 2 on 2 Dalam permainan passing 2 on 2 ini di harapkan dapat meningkatkan kemampuan passing bawah bola voli, karena di dalam permainan ini yang aslinya di mainkan oleh 12 orang yang bermain di lapangan dengan adanya modifikasi permainan bola voli 2 on 2 
ini di harapkan siswi lebih banyak mendapatkan kesempatan mendapatkan bola atau passing dari lawan mainya, karena di dalam permainan ini hanya ada 4 orang pemain di lapangan. Permainan ini juga akan lebih efektif karena permainan 2 on 2 ini siswi lebih banyak mendapatkan kesempatan mendapatkan bola, hal ini di harapkan siswi lebih bisa cepat menguasai tekhnik dasar bola voli khususnya pada passing bawah bola voli. Karena passing bawah merupakan kunci jalanya permainan bola voli untuk mendapatkan poin dan meraih kemenangan.

\section{METODE PENELITIAN}

Model pengembangan yang digunakan dalam penelitian ini adalah pendekatan model penelitian dan pengembangan Research and Development (R\&D). Borg \& Gall (1983), namun hanya 6 (enam) langkah yang dilakukan yaitu sebagai berikut : Penelitian dan Pengumpulan Informasi (Research and Information Collectin, Perencanaan (Planning), Pengembangan Produk Pendahuluan (Develop Premilinary Form of Product), Uji Coba Pendahuluan (Preliminary Field Testing), Perbaikan Produk Utama (Main Mroduct Revision), Uji Coba Utama (Main Field Testing).

\section{HASIL DAN PEMBAHASAN}

Setelah pengembangan produk awal selesai, kemudian dilakukan validasi yaitu penilaian terhadap model Permainan yang dikembangkan. Validasi dilakukan dengan cara mengisi angket dengan skor yang mengacu pada spesifikasi produk dan kualitas produk. Validasi dilakukan oleh 2 orang ahli yaitu ahli penjas dan ahli pemebelajaran bola voli. Hasil uji validasi 1 mendapatkan skor 95\% dari ahli penjas dengan kategori sangat baik dan 95\% dari ahli pembelajaran bola voli dengan kategori sangat baik. Setelah itu di lakukan revisi berdasarkan evaluasi ahli, untuk hasil uji validasi ahli yang ke 2 setelah di revisi mendapatkan skor 95\% dari ahli penjas dengan kategori sangat baik dan 95\% dari ahli pembelajaran bola voli dengan kategori sangat baik. Melalui tahapan uji kelayakan dengan penilaian validasi ahli penjas dan ahli pembelajaran bola voli kemudian dilakukan uji coba skala kecil yang berjumlah 6 siswi yang mengikuti kegiatan ekstrakurikuler bola voli di Smk N 2 Blora pada tanggal 13 januari 2021. Hasil tanggapan dari peserta kegiatan ekstrakurikuler bola voli memperoleh persentase $67,4 \%$ yang termasuk dalam kategori Baik (digunakan). Setelah melakukan uji coba skala kecil peneliti melakukan validasi kepada ahli penjas dan ahli pembelajaran bola voli. Sebelum dilakukan uji coba skala besar, di lakukannya revisi produk permainan 2 on 2 berdasarkan masukan serta saran ahli penjas dan ahli pembelajaran bola voli di antara lain:

1. Peraturan harus jelas dan detail

2. 10 point di setiap permainan

3. menggunakan 2 kali sentuhan 
Journal STAND: Sports and Development

http://jurnal.unipasby.ac.id/index.php/stand/about/submissions jurnal.stand@unipasby.ac.id

Setelah produk di revisi, pada tanggal 20 januari 2021 dilakukanya uji coba lapangan utama atau uji coba skala besar pada kegiatan ekstrakurikuler bola voli di Smk N2 Blora yang berjumlah 20 siswi. Data uji coba dihimpun dengan menggunakan angaket kuesioner. Berdasarkan uji lapangan utama atau skala besar didapatkan persentase sebesar $83 \%$ yang termasuk dalam kategori baik (digunakan). Untuk itu didapatkan model akhir permainan 2 on 2 setelah dilakukannya revisi produk berdasarkan kritik dan saran ahli penjas dan ahli pembelajaran bola voli.

Dari pembahasan data hasil penelitian secara presentase, permainan passing bawah 2 on 2 di kategorikan bisa digunakan terhadap pembelajaran penjas untuk memotivasi dan menarik siswi dalam penjas khususnya pada permaianan bola voli, dikarenakan model permaianan tangkis mini sebagai berikut :

1. Peraturan permainan passing bawah 2 on 2 jelas yaitu permainan pemanasan dan permaianan inti sehingga siswi bisa mudah dalam memahami serta mengetahui aturan cara bermain dalam permainan tersebut.

2. permainan passing bawah 2 on 2 berjumlah 4 siswi pada saat melakukan permainan sehingga akan lebih banyak jumlah siswi yang aktif bergerak dalam proses pembelajaran penjas dengan permainan tersebut

\section{KESIMPULAN}

Hasil akhir dari kegiatan penelitian pengembangan ini adalah menghasilkan produk model permainan bola voli yang berdasarkan data pada saat uji coba skala kecil $(\mathrm{N}=6)$ dan uji coba lapangan utama $(\mathrm{N}=20)$. Dan bentuk permainan bola voli yang dikembangkan menjadi permainan 2 on 2 berdasarkan uji validasi ahli yaitu uji internal 1 dan uji internal 2 yang di validasi oleh ahli penjas serta ahli pembelajaran bola voli.

Berdasarkan data hasil uji coba dan pengamatan selama penelitian maka dilakukan beberapa revisi pada model permainan passing bawah 2 on 2 meliputi:

1. Revisi produk model permainan bola voli yang di lakukan peneliti adalah membuat peraturan yang detail dan jelas.

2. Revisi produk model permainan bola voli yang di lakukan peneliti adalah merubah waktu perminan yang semula 10 menit menjadi poin yaitu 10 poin di setiap permainannya.

3. Revisi produk model permainan bola voli yang dilakukan peneliti adalah memberi kesempatan 2 kali sentuhan dalam permainanya untuk mempermudah siswi melakukan atau mengontrol bola saat permainan.

Berdasarkan analisa hasil permainan, penelitian dan kajian dalam skripsi ini, maka dapat disimpulkan bahwa telah dihasilkan model pengembangan bola voli 
dalam kegiatan ekstrakurikuler bola voli di SMK N 2 BLORA. Hal itu berdasarkan Analisisis data pada pada uji internal 1 dan uji internal 2 serta analisis data pada kajian kuesioner siswi skala kecil dan kajian kuesioner siswi skala besar yang meliputi sebagai berikut :

1. Kajian Ahli Penjas dan Ahli Pembelajaran Bola voli Uji Lapangan Skala Kecil (Internal 1)

Produk model pembelajaran permainan bola voli "2 on 2" sudah dapat dipraktekkan kepada subjek uji coba. Hal itu berdasarkan hasil analisis data pada uji coba lapangan skala kecil, dari evaluasi ahli Penjas didapat rata-rata persentase 95\% dan evaluasi ahli pembelajaran bola voli di dapat rata-rata persentase $95 \%$. Berdasarkan kriteria yang telah ditetapkan maka produk permainan bola voli " 2 on 2 " ini telah memenuhi kriteria baik sehingga dapat digunakan untuk siswi yang mengikuti kegiatan ekstrakurikuler bola voli di SMK N 2 Blora.

2. Kajian Ahli Penjas dan Ahli

Pembelajaran B0la voli Uji Lapangan

Skala Besar (Internal 2)

Produk model pembelajaran permainan bola voli 2 on 2 sudah dapat dipraktekkan kepada subjek uji coba. Hal itu berdasarkan hasil analisis data pada uji coba lapangan skala besar, dari evaluasi ahli penjas didapat rata-rata persentase $95 \%$ dan hasil analisis data dari evaluasi ahli Pembelajaran Bola voli didapat rata-rata persentase 95\%. Berdasarkan kriteria yang telah ditetapkan maka produk permainan bola voli 2 on 2 ini telah memenuhi kriteria baik sehingga dapat digunakan untuk siswi yang mengikuti kegiatan ekstrakurikuler bola voli di SMK N 2 Blora.

3. Kajian Kuesioner Siswa pada Uji Skala Kecil

Produk model permainan passing bawah bola voli 2 on 2 sudah dapat digunakan bagi siswi yang mengikuti kegiatan ekstrakurikuler bola voli di SMK N 2 Blora. Hal ini berdasarkan Hasil analisis data uji coba lapangan skala kecil didapat rata-rata persentase pilihan jawaban yang sesuai $67,4 \%$. Berdasarkan kriteria yang telah ditentukan maka permainan passing bawah bola voli 2 on 2 ini telah memenuhi baik.

4. Kajian Kuesioner Siswa pada Uji Lapangan Skala Besar

Produk model permainan passing bawah bola voli sudah dapat digunakan bagi siswi. Hal ini berdasarkan hasil analisis data uji coba lapangan skala besar didapat ratarata persentase pilihan jawaban yang sesuai $83 \%$. Berdasarkan kriteria yang telah ditentukan maka permainan passing bawah bola voli 2 on 2 telah memenuhi kriteria baik.

Pembaruan pada model permainan bola voli yang di kembangkan menjadi permainan passing bawah 2 on 2 berdasarkan analisa data ahli pada uji internal 1 dan uji internal 2 yaitu sebagai berikut: 
1. Revisi produk model permainan bola voli yang di lakukan peneliti adalah membuat peraturan yang detail dan jelas.

2. Revisi produk model permainan bola voli yang di lakukan peneliti adalah merubah waktu perminan yang semula 10 menit menjadi poin yaitu 10 poin di setiap permainannya.

3. Revisi produk model permainan bola voli yang dilakukan peneliti adalah memberi kesempatan 2 kali sentuhan dalam permainanya untuk mempermudah siswi melakukan atau mengontrol bola saat permainan.

\section{REFERENSI}

Yoga Tri Gumilang1), G. R. (2019). MODIFIKASI ALAT TERHADAP KEMAMPUAN PASSING BAWAH. Journal of S.P.O.R.T, Vol. 3, No.1, Mei 2019, 3, 56-61.

Haryanto, T. S. (2015). PENGEMBANGAN PEMBELAJARAN PERMAINAN BOLAVOLI MENGGUNAKAN MEDIA INTRAKTIF DI SMP N 6 KABUPATEN SITUBONDO. Volume 25, Nomor 1, Tahun 2015, 25, 123-128.

Erliana, M. (2014). PENGARUH PEMBELAJARAN BERMAIN MODEL KETERAMPILAN TERHADAP PASSING BAWAH BOLA VOLI MINI. Jurnal Multilateral, Volume 13, No. 1 Juni 2014, 13, 53-62.

Anggraini, A. W. (2016). MENINGKATKAN KETERAMPILAN PASSING BAWAH MENGGUNAKAN LATIHAN BERVARIASIPADA
SISWA

PESERTA

EKSTRAKURIKULER BOLA VOLI SMK N 2 SINGOSARI KABUPATEN MALANG. PENDIDIKAN JASMANI, Volume 26, Nomor 02, Tahun 2016,, 26, 365-380.

Karim, D. A. (2017). PENGARUH MODEL PEMBELAJARAN TEAM GAMES TOURNAMENT TERHADAP TEKNIK DASAR PASSING BAWAH BOLA VOLI. Doddy Abdul Karim, - Vol. II, No. 1, Juni 2017, II, 1-3.

Lubis, R. I. (2020). PENGARUH RANGKAIAN LATIHAN TERHADAP KEMAMPUAN PASSING BAWAH DAN PASSING ATAS ATLET BOLA VOLI PUTRA THE LEGEND. Jurnal Patriot Volume 2 Nomor 2, Tahun 2020, 2, 477-489.

Saputra, D. I. (2019). MENINGKATKAN HASIL BELAJAR PASSING BAWAH BOLA VOLI MELALUI PERMAINAN LEMPAR BOLA. Jurnal Pendidikan Jasmani dan Olahraga Volume 3, Nomor 1, JuliDesember 2019, 3, 64-73.

Pasaribu, A. M. (2016). PENGARUH GAYA MENGAJAR DAN MOTIVASI BELAJAR PASSING BAWAH DALAM PERMAINAN BOLA VOLI PADA SISWA SMP KELAS VIII TAHUN 2013/2014. Jurnal SPORTIF | Vol. 2 No. 2 November Tahun 2016, 2, 85-97.

HIDAYAT, S. (2018). PENGARUH METODE BERMAIN TERHADAP PENINGKATAN PASSING BAWAH DALAM PERMAINAN BOLA VOLI SISWAEKSRAKURIKULER SMK NEGERI 1 SUBANG. BIORMATIKA Jurnal Ilmiah FKIP 


\begin{tabular}{|c|c|}
\hline & Journal STAND: Sports and Development \\
uttp://jurnal.unipasby.ac.id/index.php/stand/about/submissions \\
unipa Surnalsya
\end{tabular}

Universitas Subang Vol. 4 No 01 Februari 2018, 4, 1-8.

Mu'arifuddin, M. A. (2018). PENGEMBANGAN MODEL LATIHAN PASING BAWAH KLUB BOLAVOLI IKIP BUDI
UTOMO MALANG. Jurnal SPORTIF : Jurnal Penelitian PembelajaranVolume 4 Nomor 2 Tahun 2018, 4, 50-62. 